\title{
MICROSCHEMA STAL GEN. REVAL. AND A CORRECTION IN THE LABELLING OF THE TYPE SPECIMEN OF HOPLOPHORA STRAMINICOLOR STAL (HOMOPTERA, MEMBRACIDAE) ${ }^{1}$
}

\author{
Albino M. Sakakibara ${ }^{2}$ \\ Antônio J. Creão-Duarte ${ }^{3}$
}

\begin{abstract}
The genus Microschema Stall, 1869 (type species: Hoplophora straminicolor Stål, 1862) is here reinstated and redescribed. Micropepla Sakakibara, 1979 is considered its new synonym. Microschema straminicolor (Stål, 1862), comb.n. is also redescribed and illustrated; Micropepla mourei Sakakibara, 1979, is a new synonym. The holotype of Hoplophora straminicolor Stål (in the Museum of Stockholm) was mislabelled. The correction is here made and the true type specimen duly labelled as Holotype.

KEY WORDS. Homoptera, Membracidae, Microschema, taxonomy
\end{abstract}

Microschema Stål, 1869, gen. reval.

Platycotis (Microschema) Stål, 1869: 37 (Type species: Hoplophora straminicolor Stål, 1862, monotipy). - Metcalf \& Wade, 1965: 525.

Micropepla Sakakibara, 1979: 143 (Type species: Micropepla mourei Sakakibara, 1979, original desig.), syn.n.

Microschema; McKamey \& Deitz, 1991: 194 (= Potnia Stål, 1869) (error).

Description. Head sub-triangular, strongly deflected, aproximately as wide as base of posterior process (just after humeral angles); superior margin slightly arched; eyes relatively small, rounded; ocelly conspicuous, equidistant from each other and to eyes, situated on an imaginary line that passes through center of eyes; clipeus slightly tumid, almost in the same plan of vertex; rostrum terminating between the posterior coxae.

Pronotum roughly punctured, triangular, low, convex anteriorly over the metopidium; posterior process acuminate, terminating at the level of apex of clavus; median carina percurrent; humeral angles obtuse, not projected.

Tegmina with distinct venation, corrugate between veins, costal margin and base of clavus punctate as pronotum; five apical and two discoidal cells; transverse veins $\mathbf{r}, \mathbf{r}-\mathbf{m}$ and two $\mathbf{m}$-cu present. Wings with three apical cells; transverse veins $\mathbf{r}-\mathbf{m}$ and $\mathbf{m}-\mathbf{c u}$ present; vein $\mathbf{M}$ unbranched.

1) Contribuição número 950 do Departamento de Zoologia, Universidade Federal do Paraná.

2) Departamento de Sistemática e Ecologia, Universidade Federal da Paraíba. 58059-900 João Pessoa, Paraíba, Brasil.

3) Departamento de Zoologia, Universidade Federal do Paraná. Caixa Postal 19020, 81531-990 Curitiba, Paraná, Brasil. Bolsista do CNPq. 
Legs I and II with robust tarsi, with total length more than half the length of tibiae I; legs III with clavate tibiae, without cuculate setae; tarsi small, obsolete, with total length almost equal to half the length of last tarsomere of legs I.

Comments. Stål erected Microschema as a sub-genus of Platycotis due to the wide head, almost equal in width with the base of posterior process, and the wings with three apical cells; in contrast to Potnia which head is narrower and wings with four apical cells. The wing venation in Microschema is different from that of Platycotis presenting a transverse vein $\mathbf{r}-\mathbf{m}$ and the vein $\mathbf{M}$ not branched (Fig. 4); in Platycotis the veins $\mathbf{R}_{\mathbf{4}+5}$ and $\mathbf{M}_{\mathbf{1}+\mathbf{2}}$ are confluent and the branch $\mathbf{M}_{\mathbf{3}+\mathbf{4}}$ is present.

The lateral carinae of pronotum, well evident in Potnia (Fig. 1), are not so in Microschema (Fig. 3), sometimes visible like elevate smooth lines, irregular and obsolete.

The name chosen by Stål is very suggestive: from greeck origin, Micro $=$ small + schem $a=$ form. It is the smallest representative within Hoplophorionini.

The genus Microschema Stål is represented now only by its type species, $M$. straminicolor Stål. METCALF \& WADE (1965) catalogued also Platycotis (M.) spreta Goding, 1893, but MCKAMEY \& DEITZ (1991) transferred it to Metcalfiella Goding.

\section{Microschema straminicolor (Stål, 1862), comb.n.}

\section{Figs 3-4}

Hoplophora straminicolor Stål, 1862: 25 (Type loc.: Brazil, Rio de Janeiro). Platycotis (Microschema) straminicolor; Stål, 1869: 37. - Metcalf \& Wade, 1965: 526.

Micropepla mourei Sakakibara, 1979: 144 (Type loc.: Brazil, Paraná), syn.n.

Mesurements (mm). Female/male. Width of head 1.32/1.24; Total length 4.40/3.88; length of pronotum 3.00/2.88; width between humeral angles 1.84/1.66.

Diagnose. Small; head as wide as base of posterior process; pronotum low and anteriorly convex; wings with three apical cells, transverse vein $\mathbf{r}-\mathbf{m}$ present.

Description. Female. General color pale-yellow. Head sub-triangular, strongly deflected posteriorly below ocelly, aproximately as wide as base of posterior process; eyes rounded, relatively small; superior margin slightly arched; ocelly conspicuous, equidistant from each other and to eyes, situated on an imaginary line that passes through center of eyes; clypeus slightly tumid; rostrum attaining posterior coxae.

Pronotum roughly punctured, triangular, low, convex anteriorly above metopidium, premetopidium evident; posterior process acuminate, terminating at the level of apex of clavus; median carina percurrent, the dorsal contour line somewhat sinuous; lateral carinae weak or absent; humeral angles obtuse, not projected.

Tegmina sub-hyaline, corrugate between veins; with five apical and two discoidal cells, and transverse veins $\mathbf{r}$ and two $\mathbf{m}$-cu. Wings with three apical cells, transverse vein $\mathbf{r}-\mathbf{m}$, and vein $\mathbf{M}$ unbranched.

Male. Similar, but smaller.

Material examined (only localities). BRAZIL, Minas Gerais: Barbacena 
(Serra do Caraça). Rio de Janeiro: Rio de Janeiro. São Paulo: São Paulo (Serra da Bocaina). Paraná: Curitiba. Santa Catarina: Santa Cecília. (Departamento de Zoologia, Universidade Federal do Paraná, Brazil).
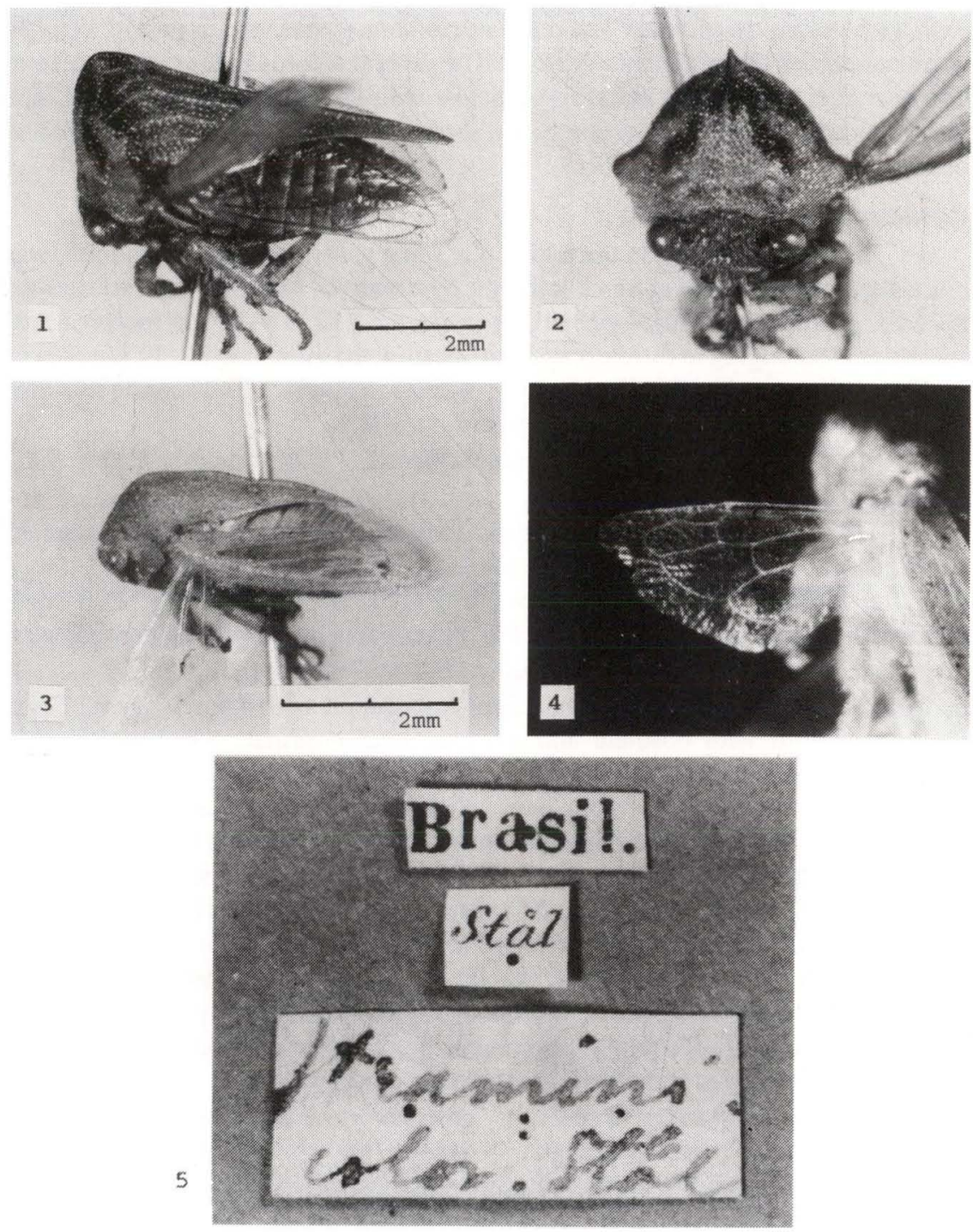

Figs 1-5. Potnia venosa (Germar, 1821). (1-2) Specimen-1, see text. Microschema straminicolor (Stål, 1862), holotype. (3) Lateral view; (4) wing; (5) labels of the holotype (specimen-2, see text). 
Holotype female of Hoplophora straminicolor Stål (Naturhistoriska Ricksmuseet, Stockholm, Sweden).

Holotype of Micropepla mourei Sakakibara (Departamento de Zoologia, Universidade Federal do Paraná, Brazil).

Comments. This species is the smallest within Hoplophorionini. The wings with only three apical cells and presence of transverse vein $\mathbf{r}-\mathbf{m}$ and vein $\mathbf{M}$ unbranched, are characteristics (Fig. 4). The general color is pale yellow (green in live specimens) but some males in particular with the metopidium darkened. The lateral carinae of pronotum properly are absent; they are represented by weak and obsolete elevate smooth lines (Fig. 3).

\section{CORRECTION OF LABELLING}

Recently, working on the revision of some genera of Hoplophorionini, was requested from Museum of Stockholm, the type material of some species described by Stål, among them Hoplophora straminicolor Stål, 1862. We received two specimens (belonging to different species), bearing the following labels: Specimen1 (Figs 1-2), a male: "Rio/Janeiro" "F. Sahlbg." "Typus" "Ricksmuseum/ Stockholm" "Holotype/Hoplophora/ straminicolor/Stål".

Specimen-2 (Figs 3-5), a female: "Brasil" "Stål" "stramini/color. Stål" "Allotypus".

The labels "Typus" and "Holotype" (with the name of the species) in the first specimen and also "Allotypus" in the second specimen, certainly were added well after Stål's work. It is important to say that the specimen-2 (Fig. 3) bears a handwritten label straminicolor. Stål (Fig. 5), probably made by the author himself.

Analising the original description of $H$. straminicolor (Stål, 1862: 25), it can be understood that it refers to a small female specimen, with $4 \mathrm{~mm}$ long and $2 \mathrm{~mm}$ wide; pronotum with obsolete and irregular lateral carinae. STÅL (1869: 37) described the genus Platycotis, and the subgenus Microschema, including in this Hoplophora straminicolor. In this paper, Stål presents a key where the diagnostic characters of the genera and subgenera are given, as: wings with three apical cells (joining Platycotis, Hoplophora and Umbonia), and with four apical cells (Triquetra and Potnia). The genus Platycotis is separated from the others by having a wide head (width of head aproximately equal to the base of posterior process). Then, Platycotis (Microschema) straminicolor (Stål, 1862) can be defined as: small, with $4 \mathrm{~mm}$ long and $2 \mathrm{~mm}$ wide; head wide, about as wide as the base of posterior process, and the superior margin straight; pronotum anteriorly low and convex, with lateral carinae obsolete and irregular; wings with three apical cells.

The definition above fits perfectly on specimen-2, instead of on specimen-1 labelled "Holotype". This specimen-1 at contrary, has $7 \mathrm{~mm}$ long and $3 \mathrm{~mm}$ wide; head narrow, with superior margin sinuous; pronotum anteriorly distinctly angulate, with lateral carinae well marked; wings with four apical cells. So, it can be deduced that someone commited a mislabelling, putting the label "Holotype" in the wrong specimen.

The specimen-1 does not belong to the type material once Stål did not refer to any other specimen in his work. 
Some clues indicate the possible causes that lead to a mislabelling, for instance: the title of Stål's work is "Bidrag till Rio Janeiro tracktens Hemipter-fauna". The specimen- 1 bears the proceeding label "Rio Janeiro"; the specimen-2, only "Brasil". The first received the label "Holotype" (maybe because of Rio Janeiro in the label) and the second (even with the handwritten name) "Allotypus".

Our suspicion about a mislabelling began when we tried to respond some questions, having in hand the specimen-1. Did Stål really equivocate about the sex of the type specimen? Were the mensurations of the type specimen wrong? How the definition of wide head aplies here? Why the lateral carinae, well marked, were interpreted as obsolete? and the anterior part of pronotum, strongly angulate, as low and convex? Wings with three apical cells instead of four?

It is sure that Stål would not commit so many mistakes.

Based on the evidences, the specimen-2 is relabelled (Fig. 3) (with the data given above) as the true Holotype of Hoplophora straminicolor Stål, 1862. The specimen-1 (Fig. 1) (with the data given above), that does not belong to the type material, the labels "Typus" and "Holotype" are eliminated, and was added an identification label "Potnia venosa (Germar, 1821)", confirming what said MCKAMEY \& DEITZ (1991) after examining the specimen.

\section{REFERENCES}

GoDING, F.W. 1893. Bibliographical and synonymical catalogue of the described Membracidae of North America. Illinois State Laboratory of Natural History Bulletin 3: 391-482.

MCKAMEY, S.H. \& L.L. DeITZ. 1991. Nomenclatural changes in the treehopper tribes Hoplophorionini, Smiliini, and Talipedini (Homoptera: Membracidae). Proc. Ent. Soc. Wash. 93 (1): 193-196.

MetCALF, Z.P. \& V. WADE. 1965. General Catalogue of the Homoptera. Raleigh, North Carolina State University, 1552p.

SAKAKIBARA, A.M. 1979. Micropepla mourei gen.n., sp.n. de Hoplophorioninae (Homoptera, Membracidae). Dusenia 11 (3): 143-146.

STÅL, C. 1862. Bidrag till Rio-Janeiro tracktens Hemipter-fauna. Ofvers. af Svenska Vetens. Akad. Forh. 3 (6): 1-75. $1-130$.

1869. Hemiptera Fabriciana. Svens. Vetensk. Akadem. Forhandl. 8 (1):

Recebido em 17.VI.1996; aceito em 20.XII.1996. 